\title{
Chapter 10 \\ Life Cycle Assessment Applied in Rice Production and Residue Management
}

\author{
Nguyen Van Hung, Maria Victoria Migo, Reianne Quilloy, Pauline Chivenge, \\ and Martin Gummert
}

\begin{abstract}
Rice production can be carried out using a wide set of cultivation techniques. Different land preparation, crop establishment, crop care, harvesting, and straw management techniques lead to different environmental impacts. Life-cycle assessment (LCA) is a reliable tool for assessing the environmental load of agricultural processes and can be used to compute or simulate energy balance and environmental impact categories such as climate change, ozone depletion, terrestrial acidification, freshwater eutrophication, and marine eutrophication. This chapter comprises the following sections: (1) LCA overview and application in agriculture, (2) case studies of LCA to identify the best rice straw management practices, and (3) summary and suggestions for further applications.
\end{abstract}

Keywords Life cycle assessment · LCA · Impact assessment · Energy balance · GHG emissions balance

\subsection{Introduction}

Crop production (during the crop's life cycle) is done using a wide set of cultivation techniques and crop management, harvest, and postharvest procedures. The processes and relevant inputs and outputs, which are part of the life-cycle process, are shown in Fig. 10.1. Rice production is typically characterized by three major phases: preplanting, plant growth, and postproduction.

\footnotetext{
N. V. Hung $(\bowtie) \cdot$ R. Quilloy $\cdot$ P. Chivenge $\cdot$ M. Gummert International Rice Research Institute (IRRI), Los Baños, Laguna, Philippines e-mail: hung.nguyen@irri.org; r.quilloy@irri.org; p.chivenge@irri.org; m.gummert@irri.org

M. V. Migo

Department of Chemical Engineering, College of Engineering and Agro-Industrial Technology, University of the Philippines Los Baños (UPLB), Los Baños, Laguna, Philippines

e-mail: mpmigo@up.edu.ph
} 


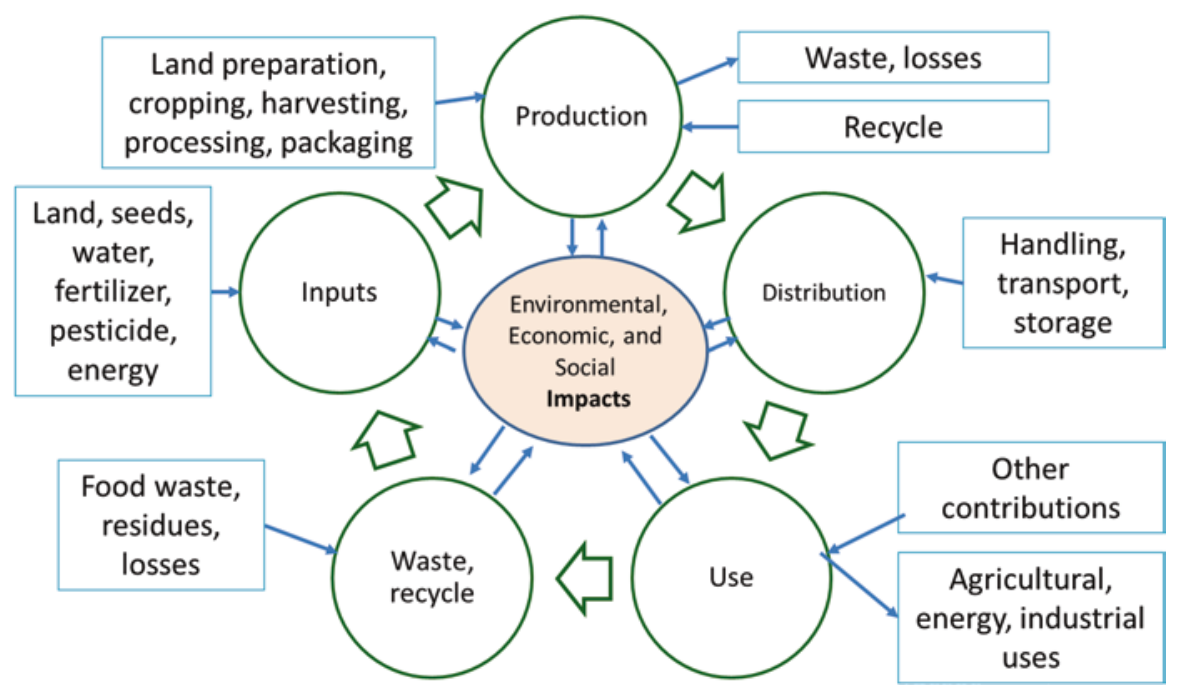

Fig. 10.1 Rice production life cycle

In preplanting, the variety is chosen and the field is prepared for planting. Land preparation consists of plowing or overturning the soil, harrowing or breaking the soil into smaller masses, and leveling the field. Equipment, which can be used in mechanized land preparation, include the power tiller, moldboard plow, hydrotiller, and rotovator. If herbicide is applied to kill weeds, the land is irrigated from 2 to 3 days after its application.

In the plant growth phase, rice is either directly seeded or transplanted. Fertilizers, pesticides, and herbicides are applied and, traditionally, the land is continuously flooded since rice is very sensitive to water shortages. Improved water management options, such as alternate wetting and drying (AWD), have been developed recently to conserve water and reduce greenhouse gas emissions (Carrijo et al. 2017; Linquist et al. 2015). Snails, which are persistent pests during this period, can be managed by manual removal or chemical control. During the growth phase, it is also important to apply N-P-K fertilizers and pesticides and herbicides (when necessary) to enhance yield. In addition, it is imperative to manage the water level to sustain the crop and control weeds.

Postproduction activities include harvesting, drying, storage, milling, and processing. Harvest operations include reaping, threshing, cleaning, hauling, field drying, piling, and bagging. Harvesting may involve traditional manual labor for all steps, semi-mechanical using a machine thresher, or full mechanization using a combine harvester. After combine harvesting, rice straw is left on the field and can either be collected, burned, or left to decompose (on the surface or after soil incorporation). When manually harvested, the rice stalks are cut and moved to a central threshing area, leaving behind uncut rice straw stubble, which can be burned or incorporated into the soil. Loose rice straw and stubble are considered byproducts. The paddy is then dried (traditional sun drying, solar drying, or mechanical drying) 
to reduce the moisture content to about $14 \%$, which helps to prevent grain discoloration, mold formation, and insect attack. The paddy can be stored or milled to remove the husks and bran layers revealing the edible white kernels. The rice husks and bran are considered to be byproduct as well.

Life cycle assessment (LCA) is a tool for the analysis of the energy balance and environmental impacts of a process from cradle to grave, beginning with the gathering of raw materials from the earth to create the product and ending at the point when all materials are returned to the earth (US EPA 2006). LCA can be applied to compute or simulate energy balance and environmental impact categories, such as climate change, ozone depletion, terrestrial acidification, freshwater eutrophication, and marine eutrophication. LCA can also be applied for crop production and agricultural systems for the following purposes:

- Comparative analyses and identification of the best options among different production systems, practices, technologies based on some specific economic and environmental factors;

- Production process improvement, product development, and promotion; and

- Strategic planning and decision support.

\subsection{LCA Framework}

The LCA framework (Fig. 10.2) based on the ISO 14040 (Guinée et al. 2001) includes the following main components: (1) definition of goal, scope, and function unit; (2) inventory analysis; (3) impact assessment; and (4) interpretation. According to ISO 14040, the goal should contain an unambiguous description of the LCA's application and intended audiences as well as the reasons for conducting the study.

\begin{tabular}{|c|c|c|}
\hline Goal: application, intended & \multirow{5}{*}{$\begin{array}{l}\text { Interpretation: } \\
\text { LCA report; } \\
\text { Scientific } \\
\text { evidences of } \\
\text { impacts; } \\
\text { Sustainability } \\
\text { analysis }\end{array}$} & \multirow{5}{*}{$\begin{array}{l}\text { Applications in } \\
\text { agriculture: } \\
\checkmark \text { Comparing and } \\
\text { identifying best options } \\
\text { among different } \\
\text { production systems, } \\
\text { practices, technologies } \\
\text { based on the economic } \\
\text { and environmental } \\
\text { factors. } \\
\checkmark \text { Production process } \\
\text { improvement, product } \\
\text { development, and } \\
\text { promotion } \\
\checkmark \text { Strategic planning and } \\
\text { decision support }\end{array}$} \\
\hline $\begin{array}{l}\text { audiences, rationale } \\
\text { Scope: boundary, assumptions, }\end{array}$ & & \\
\hline $\begin{array}{l}\text { Function unit: measure of } \\
\text { function for the studied systems }\end{array}$ & & \\
\hline $\begin{array}{l}\text { Inventory analysis : data } \\
\text { collection, conversion factors, } \\
\text { inventory results }\end{array}$ & & \\
\hline $\begin{array}{l}\text { Impact assessment: climate } \\
\text { change, ozone depletion, } \\
\text { terrestrial acidification, etc. }\end{array}$ & & \\
\hline
\end{tabular}

Fig. 10.2 LCA framework and applications 


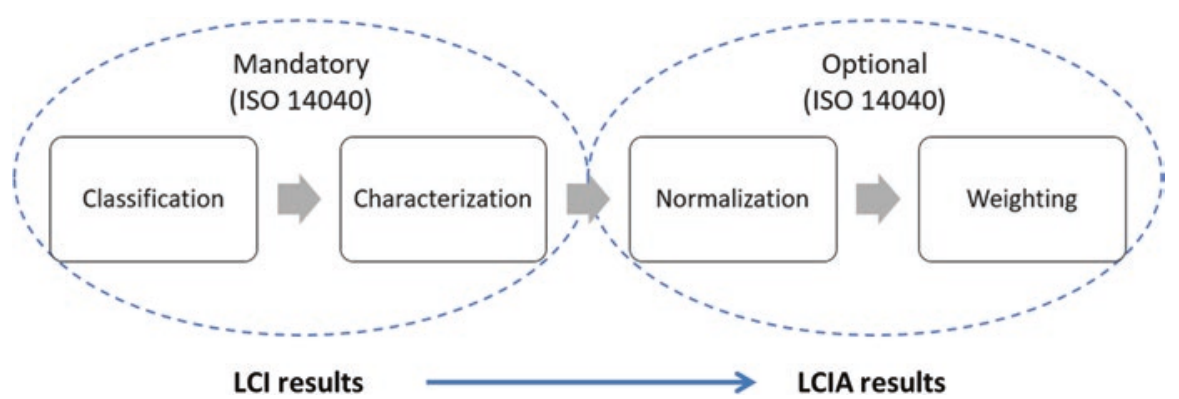

Fig. 10.3 LCIA steps (ISO 14040)

On the other hand, the scope should describe the most important methodological assumptions and limitations (PRé Product Ecology Consultants 2013). At this stage of the LCA, the functional unit or comparison basis is also defined. An example in rice science is the most common functional units of per $\mathrm{kg}$ or per ton of grain harvested. After defining the goal, scope, and functional unit, it is suggested to specify a system boundary that will determine which processes will be included in the LCA.

The life cycle inventory (LCI) involves listing all inputs and outputs and collecting data related to unit processes within the system boundary (Guinée 2004). In rice production, one input is the seed and one output is the grain. Thus, data collection on grain yield is necessary. The product of this step is called the LCI result. In some cases, systems have multi-functionality, as with rice production where there are two products, paddy and straw. Such cases require the LCA practitioner to allocate the inputs and outputs between the two products. However, according to the ISO 14040 standard, such allocation should be avoided as much as possible (Agri-footprint 2015). If allocation is unavoidable, the system inputs and outputs can be divided across mass allocation, gross energy allocation, and/or economic allocation (Agrifootprint 2015). Mass allocation is based on the mass or dry matter of the products. Gross energy allocation is based on the nutritional feed material list. Economic allocation is based on the prices of the products.

The next step, life cycle impact assessment (LCIA), is based on the LCI results as shown in Fig. 10.3. This analysis involves classification, characterization, normalization, and weighting, which are calculated based on ISO 14040. According to ISO 14040, classification and characterization are mandatory while normalization and weighting are optional.

\subsubsection{Classification}

Classification is a step in the identification of impact categories from LCI results (Fig. 10.4). LCI results include data on all inputs, such as land use, water, fuel consumption, labor, fertilizer, pesticides, and insecticides, and other direct emissions, such as $\mathrm{CH}_{4}, \mathrm{~N}_{2} \mathrm{O}, \mathrm{CO}_{2}$, particulate matter $\left(\mathrm{PM}_{2.5}\right.$ and $\left.\mathrm{PM}_{10}\right)$, etc. The calculated 


\begin{tabular}{|c|}
\hline Inventory parameters \\
\hline Land (area, type..) \\
\hline Water use \\
\hline Seed \\
\hline N, P, K fertilizer \\
\hline Pesticide \\
\hline CH4, NOx, CO... \\
\hline Mechanized operations \\
\hline
\end{tabular}

Fig. 10.4 Example of LCIA classification based on LCI results

results are classified into the impact categories, such as land use, water depletion, climate change, etc.

The results of different impacts are then translated into mass of $\mathrm{CO}_{2}$ equivalent (for GWP or global warming potential), 1,4 dichlorobenzene-equivalent (for human toxicity), etc. This step is called characterization.

LCA indicators are measurable representations of an impact category. Description of the LCA indicators could be found in ISO 14040 and CML-1992 and -2001 (Jeroen et al. 2001; Budavari et al. 2011; De-Schryver et al. 2009; European Commission Joint Research Centre 2009; Guinée et al. 2001). Global warming indicators are presented in IPCC (2006). SIMAPRO is just one of many available LCA softwares or tools that incorporate indicators (SIMAPRO 2017). An overview of common indicator categories follows, particularly for rice production.

(a) Resources

- Depletion of abiotic resources: the depletion of nonliving natural resources such as soil nutrients, etc. It can be described as the fraction of resource extracted over the recoverable reserves of that source. It is expressed in $\mathrm{kg}$, $\mathrm{m}^{3}$, or MJ year ${ }^{-1}$.

- Cumulative energy demand: the total energy demand for production, including direct and indirect energy inputs. Direct energy inputs for crop production usually include agronomic inputs, fuel consumption, labor, etc.; while indirect energy inputs include the energy for production used by machines and other related infrastructures. The value is expressed in MJ.

- Water consumption: the impacts of water shortages due to groundwater extraction, expressed in $\mathrm{m}^{3}$.

- Land use: highly relevant for crop production and alternative options for using land, expressed in area units (e.g., ha).

\section{(b) Air Pollution}

- Global warming potential: the greenhouse effect instigated by the emissions of crop production from human activities. Greenhouse gas emissions 
(GHGEs), such as $\mathrm{N}_{2} \mathrm{O}$ and $\mathrm{CH}_{4}$, intensifies the heat radiation absorption of the earth's atmosphere resulting to increasing surface temperatures. It is expressed in terms of mass (e.g., $\mathrm{kgCO}_{2}$ equivalents).

- Ozone depletion potential: the thinning of the ozone layer in the stratosphere due to emissions from human activities which causes a potential damage to human health, ecosystems, biochemical cycles, and materials. It is described as the ratio between the amount of ozone destroyed by a unit of a substance and a reference substance, which is usually Trichlorofluoromethane (CFC11). It is expressed in kg-CFC-11 equivalents.

- Acidification potential: the acidity of water and soil systems can be increased due to acid deposition from the atmosphere, mainly in the form of rain. Sulfur dioxide $\left(\mathrm{SO}_{2}\right)$, ammonia $\left(\mathrm{NH}_{3}\right)$ released through volatilization, and nitrogen oxides (NOx) emitted by combustion processes (such as burning rice straw) causes "acid rain." It is expressed in $\mathrm{kg}-\mathrm{SO}_{2}$ equivalents.

\section{(c) Water Pollution}

- Eutrophication potential: the increase of the concentration of nutrients, chiefly nitrogen $(\mathrm{N})$ and phosphorus $(\mathrm{P})$, in a body of water caused by the runoff of synthetic fertilizers from agricultural land or by the input of sewage or animal waste. It causes the reduction in species diversity and the overpopulation of a dominant species, which is usually algae - a phenomenon called "algal bloom". In turn, the increased production of dead biomass from algae consumes oxygen thru a degradation process, and depletes the oxygen in the water. It is expressed in phosphate $\left(\mathrm{PO}_{4}{ }^{3-}\right)$ equivalents.

- Aquatic ecotoxicity: the impact on fresh water ecosystems as a result of emissions of toxic substances into air, water, and soil. It is expressed as 1,4-dichlorobenzene equivalents (1,4 DB-eq) per $\mathrm{kg}$ of emission.

\section{(d) Soil Pollution}

- Terrestrial ecotoxicity: the impact of toxic substances released into terrestrial ecosystems. It is defined as the potential of terrestrial toxicity of each substance emitted into the air, water, and/or soil and expressed as 1,4 DB-eq per $\mathrm{kg}$ of emission.

\section{(e) Damage, Health, and Biodiversity}

- Human toxicity potential: the impact on human health of toxic substances present in the environment. Human toxicity is identified as the overall impact of toxic substances into air, water, and soil, which are most vulnerable to pollution and contamination, such as carbon monoxide (CO), black carbon from straw burning, heavy metal loads in water and soil, etc. These toxic substances accumulate in the vegetables, fruits, meat, milk and other animal products which in turn are ingested by humans. It is expressed in $\mathrm{kg}$ of 1,4 DB-eq.

- Disability-adjusted life years (DALY): It is the total years of life lost by premature mortality and the lost of productive life due to incapacity (Goedkoop and Spriensma 2001). This indicator, expressed in DALY $\mathrm{kg}^{-1}$ of emission, determines amounts of heavy metals and carcinogenic substances. 


\subsubsection{Normalization and Weighting}

Normalization is a process to calculate the magnitude of the results of the impact indicators, relative to some reference information. Normalized results of the characterized factors, such as for each person per year, are calculated by dividing the characterized results by the normalization factors, which are standardized in ISO 14044 (Guinée et al. 2001). Normalization factors are different for midpoint and endpoint impact categories. These are described in Budavari et al. (2011).

Weighting is aimed at expressing the impact results for each category in numerical factors. Weighting is based on value choices or votes. For instance, there are different votes for the importance of different categories, e.g., climate change and human toxicity, in different regions or countries. Weighting factors of some common impact categories are presented in Budavari et al. (2011) and Guinée et al. (2001).

Table 10.1 provides an example of the characterization, normalization, and weighting steps.

As shown in Table 10.1, normalized results indicate that burning 1 ton of rice straw contributes to $2.3 \%(0.0229)$ of climate change impact and $0.15 \%(0.0015)$ of human toxicology impact of an average person in a year. The total weighting result accounted for these two impact factors is 0.51 , which is referred as an impact score to compare with other scenarios.

Of the different steps, a bulk of the work is done in the LCI and LCIA. An LCA tool, such as SIMAPRO software, aids in the calculations during the LCIA. One advantage of using an LCA tool is the availability of global and regional databases, which contain data that are impossible to measure during the scope of the study. An example in rice science is the amount of energy expended to make $1 \mathrm{~kg}$ of fertilizer. These data are required to calculate the amount of energy in producing $1 \mathrm{~kg}$ of paddy or straw and the LCA practitioner using the software usually refers to data in

Table 10.1 Characterization, normalization, and weighting, for example, of rice-straw burning

\begin{tabular}{|c|c|c|c|}
\hline \multicolumn{2}{|l|}{ LCI results } & \multirow[b]{2}{*}{$\begin{array}{l}\text { Climate change: } \\
\text { GWP-100a ( } \mathrm{kg} \mathrm{CO}_{2} \text {-eq) }\end{array}$} & \multirow{2}{*}{$\begin{array}{l}\text { Human toxicity } \\
\text { potential (kg 1,4 } \\
\text { DB-eq) }\end{array}$} \\
\hline Factors & $\begin{array}{l}\text { Emissions } \\
\left(\mathrm{kg} \mathrm{t}^{-1} \text { of straw }\right)\end{array}$ & & \\
\hline $\mathrm{CH}_{4}$ & 4.5 & $X 30.5=137.3$ & - \\
\hline $\mathrm{N}_{2} \mathrm{O}$ & 0.07 & X $265=18.6$ & - \\
\hline $\mathrm{PM}_{2.5}$ & 10 & - & $\mathrm{X} 0.82=8.2$ \\
\hline $\mathrm{PM}_{10}$ & 6 & - & $X 0.82=4.9$ \\
\hline Characterized results & & $155.8 \mathrm{~kg} \mathrm{CO}_{2}$-eq & $13.1 \mathrm{~kg} 1,4 \mathrm{DB}-\mathrm{eq}$ \\
\hline $\begin{array}{l}\text { Normalization factor } \\
\text { (Budavari et al. 2011) }\end{array}$ & & $\begin{array}{l}6803 \mathrm{~kg} \mathrm{CO}_{2} \text {-eq/person/ } \\
\text { year }\end{array}$ & $\begin{array}{l}8800 \mathrm{~kg} 1.4 \mathrm{DB}-\mathrm{eq} / \\
\text { person/year }\end{array}$ \\
\hline Normalized results & & 0.0229 person-year & 0.0015 person-year \\
\hline $\begin{array}{l}\text { Weight factor (Budavari } \\
\text { et al. 2011) }\end{array}$ & & 21.6 & 8 \\
\hline $\begin{array}{l}\text { Weighting results for the } \\
\text { two factors }\end{array}$ & & 0.51 & \\
\hline
\end{tabular}


the literature via the built-in libraries. Therefore, knowledge on the actual composition of the fertilizer is necessary to correctly select the appropriate data from the libraries. Another responsibility of the practitioner is to review the documentation that comes with the databases to check compatibility of the data.

Lastly, the interpretation step is done by making well-balanced conclusions and recommendations based on the LCIA (Guinée 2004). This is also where sensitivity and uncertainty analyses can be made.

\subsection{Some Typical and Advanced Analyses in LCA}

\subsubsection{Analyzing Energy and GHGE Balances}

Energy and GHGE balances can be analyzed in LCA and calculated based on the following steps and equations:

- Net $=\sum$ output $-\sum$ input

- Net balance factor $=$ Net $/ \sum$ input

- Net energy: $N E=\sum_{\mathrm{i}=1}^{\mathrm{n}}$ output energy $_{\mathrm{i}}-\sum_{\mathrm{j}=1}^{\mathrm{m}}$ input energy $_{\mathrm{j}}$

- Net energy balance $=N E / \sum_{\mathrm{j}=1}^{\mathrm{m}}$ input_energy $_{\mathrm{j}}$

- GHGE balance: Net GHGE $=\sum$ GHGE of products and avoided products $-\sum$ GHGE of productions (inputs and emissions)

In rice science, the input energy for the supply chain accounts for rice cultivation, harvesting, collection and transportation of products (e.g., paddy and rice straw), storage of products, and processing. For rice cultivation, the input should cover energy from rice seeds, fertilizers, pesticides, fuel consumption, machine production, and labor.

\subsubsection{Sensitivity and Uncertainty Analyses}

An analysis model with the correlation of inputs, simulation process, outputs, and feedbacks is shown in Fig. 10.5. Data distribution, error, and affecting scenarios of the input models will affect the output models. Sensitivity analysis measures the change in the outputs affected by the scenarios of actual events or assumed in the inputs. On the other hand, uncertainty analysis is used to describe the entire set of possible outcomes, together with their associated probabilities of occurrence. The Monte Carlo computational algorithm is a common method used in uncertainty analysis. These methods are incorporated in some LCA software, such as SIMAPRO (2017). 


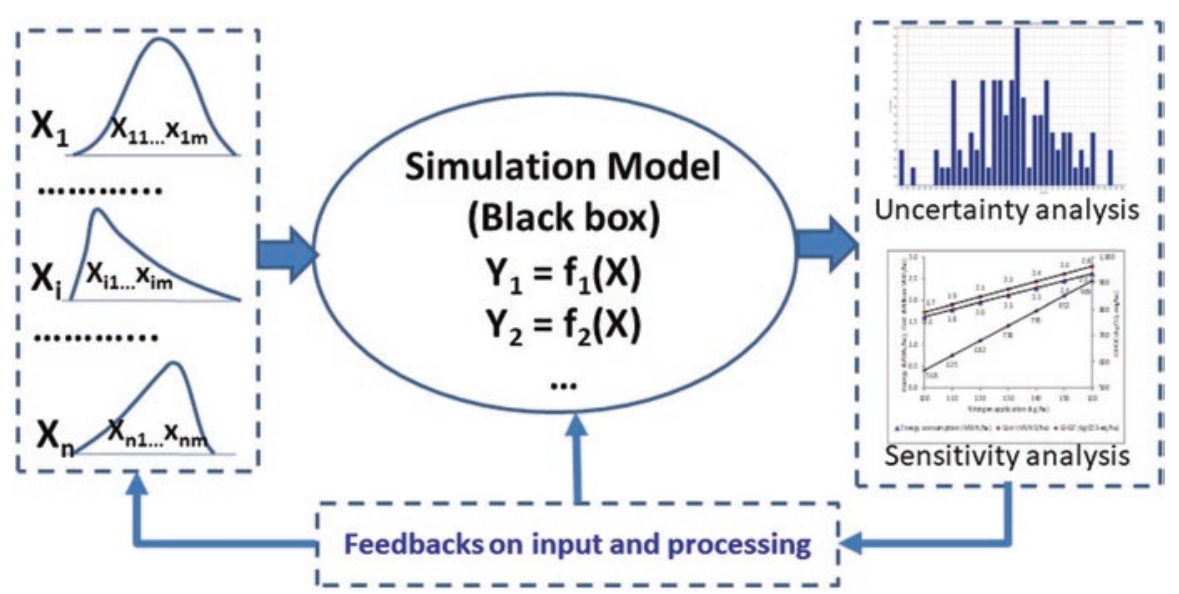

Fig. 10.5 Analysis model with the correlation of inputs, simulation process, outputs, and feedbacks

\subsection{Case Study Using LCA and SIMAPRO for Rice Production}

LCA research relevant to agricultural products or processes can be found in recent publications on rice straw bioenergy (Shie et al. 2011; Kami et al. 2012; Singh et al. 2013), rice straw biofuel and fertilizer (Silalertruksa and Gheewala 2013), power generation (Suramaythangkoor and Gheewalal 2011; Shafie et al. 2014), rice production (Brodt et al. 2014), rice straw management (Fusi et al. 2014), rice straw anaerobic digestion (Nguyen et al. 2016), and rice straw collection (Nguyen et al. 2017).

Here we present a case study on rice production for different rice straw management practices based on research conducted at IRRI from 2015 to 2016 (Nguyen et al. 2019). The goal and scope of the study were to compare environmental profiles, grain yield and quality, energy efficiency, and GHGEs of rice production at the IRRI farm during the 2015 wet season and 2016 dry season, followed by four different rice-straw management options: retaining the straw and incorporation, straw burning, partial straw removal, and complete straw removal through LCA (Fig. 10.6). The functional unit of the system is 1 ha of rice production and the impact results were translated to $1 \mathrm{t}$ of rice based on the yield data.

For life-cycle inventory analysis, we measured operations and agricultural inputs of rice production on the IRRI farm (including grain yield and total biomass) during the 2015 wet and 2016 dry seasons. Soil sampling and analysis were also conducted. Inputs and outputs for each process in the system boundary (Fig. 10.6) were itemized. For LCIA, single scores on net energy and net GHGEs were evaluated. This step was done with the aid of SIMAPRO software. Data on net energy values 


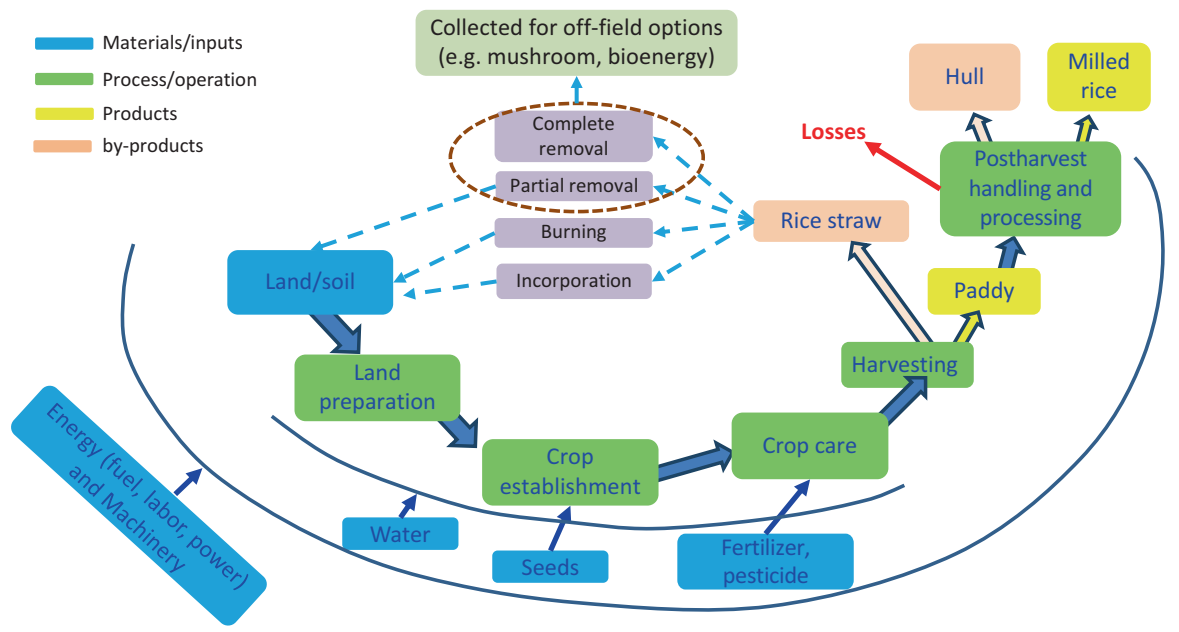

Fig. 10.6 Research boundary of LCA in rice production with different rice-straw management options. (Adapted from Nguyen et al. 2019)

Table 10.2 Energy and GHGE conversion factors of fuel, agronomic inputs, and products

\begin{tabular}{|c|c|c|c|c|c|c|}
\hline \multirow[b]{2}{*}{ Parameters } & \multicolumn{3}{|l|}{ Energy } & \multicolumn{3}{|l|}{ GHGE } \\
\hline & Unit & Value & Sources & Unit & Value & Sources \\
\hline Seeds & $\mathrm{MJ} \mathrm{kg}^{-1}$ & 30.1 & $\mathrm{a}, \mathrm{b}$ & $\mathrm{kgCO}_{2}$-eq kg-1 & 1.12 & $a, b, j$ \\
\hline Grain & $\mathrm{MJ} \mathrm{kg}^{-1}$ & 15.2 & $\mathrm{c}$ & & & \\
\hline Diesel consumption & $\mathrm{MJ} \mathrm{L}^{-1}$ & 44.8 & $\mathrm{a}, \mathrm{b}, \mathrm{d}, \mathrm{e}$ & $\mathrm{kgCO}_{2}$-eq. $\mathrm{MJ}^{-1}$ & 0.08 & $\mathrm{a}, \mathrm{b}, \mathrm{j}$ \\
\hline Machine production & $\mathrm{MJ} \mathrm{L}^{-1}$ & 15.6 & $\mathrm{~d}, \mathrm{e}, \mathrm{f}$ & & & \\
\hline Nitrogen $(\mathrm{N})$ & $\mathrm{MJ} \mathrm{kg}^{-1}$ & 58.7 & $\mathrm{a}, \mathrm{b}, \mathrm{g}$ & $\mathrm{kgCO}_{2}$-eq kg ${ }^{-1}$ & 5.68 & $\mathrm{a}, \mathrm{b}, \mathrm{j}$ \\
\hline $\mathrm{P}_{2} \mathrm{O}_{5}$ & $\mathrm{MJ} \mathrm{kg}^{-1}$ & 17.1 & $a, b, g$ & $\mathrm{kgCO}_{2}$-eq $\mathrm{kg}^{-1}$ & 1.09 & $a, b, j$ \\
\hline $\mathrm{K}_{2} \mathrm{O}$ & $\mathrm{MJ} \mathrm{kg}^{-1}$ & 8.83 & $\mathrm{a}, \mathrm{b}, \mathrm{g}$ & $\mathrm{kgCO}_{2}$-eq kg-1 & 0.52 & $a, b, j$ \\
\hline Herbicide & $\mathrm{MJ} \mathrm{kg}^{-1}$ & 354 & $\mathrm{a}, \mathrm{b}, \mathrm{h}, \mathrm{i}$ & $\mathrm{kgCO}_{2}$-eq kg-1 & 23.3 & $a, b, j$ \\
\hline
\end{tabular}

a: Ecoinvent (2017), b: SIMAPRO (2017), c: Pimentel and Pimentel (2008), d: Bowers (1992), e: Richard (1992), f: Dalgaard et al. (2001), g: Kool et al. (2012), h: Mudahar and Hignett (1987), i: Grassini and Cassman (2011), j: IPCC (2013)

of rice straw off-field activities, as well as conversion factors, were adapted from the literature and databases from the SIMAPRO software.

The energy and GHGE conversion factors for agronomic inputs, processes, and products are presented in Table 10.2. The energy value and GHGE conversion factors of related materials were based on Ecoinvent database 3.0, which is one of the databases included in SIMAPRO software (Ecoinvent 2017), global warming potential over a period of 100 years (GWP-100a) of IPCC (2013) incorporated in SIMAPRO software (SIMAPRO 2017). The energy conversion for each manual labor agronomic activity conducted in rice production was adapted from Quilty et al. (2014). Global warming factors-100 years (GWP-100a) of $\mathrm{CH}_{4}$ and $\mathrm{N}_{2} \mathrm{O}$ were 30.5 and $265 \mathrm{~kg} \mathrm{CO}_{2}$-eq., respectively. 
Production inventory data of energy and GHGE per unit of fertilizer chemicals refer to $1 \mathrm{~kg} \mathrm{~N}$ in urea ammonium nitrate with an $\mathrm{N}$-content of $32 \% ; 1 \mathrm{~kg} \mathrm{P}_{2} \mathrm{O}_{5}$ in ammonium nitrate phosphate with a $\mathrm{N}$-content of $8.4 \%$ and a $\mathrm{P}_{2} \mathrm{O}_{5}$-content of $52 \%$; and $1 \mathrm{~kg} \mathrm{~K}_{2} \mathrm{O}$ in potassium chloride with a $\mathrm{K}_{2} \mathrm{O}$-content of $60 \%$. These data take into account production activities including transport of raw materials and intermediate products but do not account for waste treatment of catalysts, coating, and packaging. Similarly, energy and emission factors of herbicides are accounted for during their life cycle during production. Energy consumption and GHGE of machines were calculated based on $44.8 \mathrm{MJ} \mathrm{L}^{-1}$ of diesel (Ecoinvent 2017) accounted for production, transportation, and combustion in machinery. In addition to that, this value was added with $15 \mathrm{MJ} \mathrm{L}^{-1}$ for machine production (Bowers 1992; Dalgaard et al. 2001).

One of the findings from this study shows a comparison among the different ricestraw management scenarios (Fig. 10.7). Results show that incorporation of rice straw in the soil causes the highest GHGE whereas removal of rice straw reduces this impact significantly. Burning rice straw in the field causes not only high GHGE but also the highest human toxicology impact. Moreover, this burning scenario has the lowest net energy balance as it causes all the $\mathrm{N}$ contained in rice straw to be lost during burning. The study illustrates that rice straw removal from the field for purposes of mushroom or bioenergy production can effectively improve energy efficiency and reduce the environmental footprint of irrigated lowland rice production in Southeast Asia where straw burning is commonly practiced.

However, the presented data were obtained from a two-season experiment at a specific area in the Philippines, and thus might have limited scope for conclusions on national and global scales. Additional data from other regions or long-term

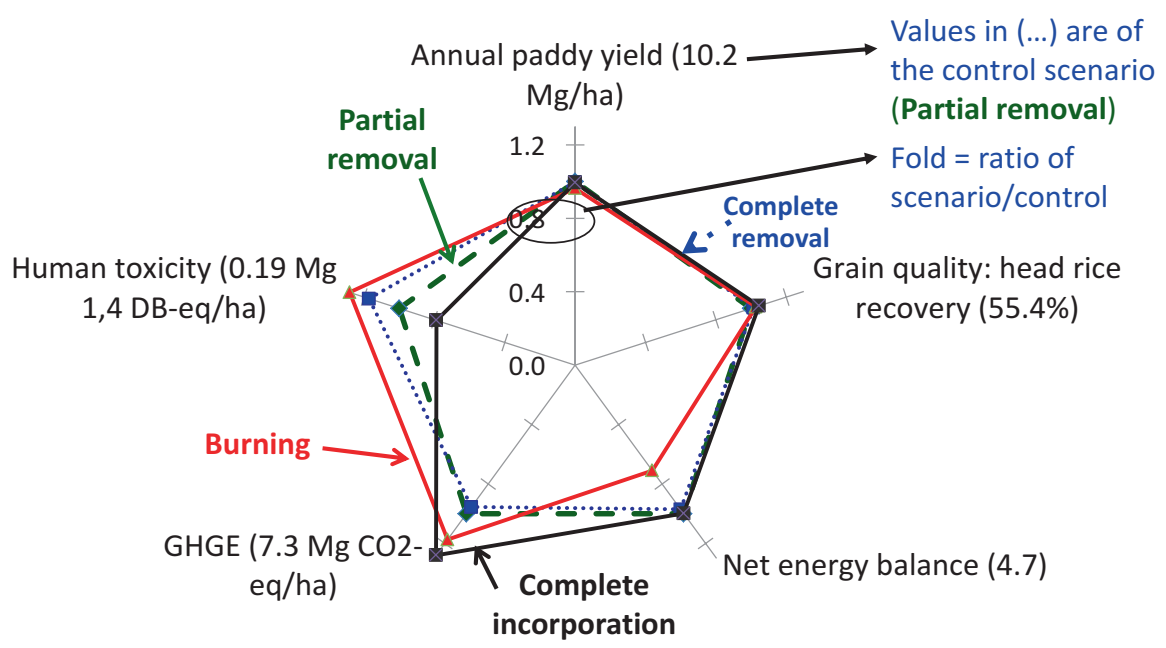

Fig. 10.7 Comparison of different rice-straw management scenarios. (Adapted from Nguyen et al. 2019) 
experiments should be gathered and more utilization options of rice straw, such as for production of bio-char, compost, cattle fodder, bio-board, or bio-plastic, should be included in the LCA for a more comprehensive picture of the environmental footprint of different straw management alternatives.

\subsection{Summary and Suggestions for Further Applications}

LCA is used globally, in such programs as the Sustainability Consortium, ISO, UNEP, and others. In rice science, LCA should be used comprehensively to identify best practices of sustainable rice production, postharvest management, and ricestraw management. Energy balances, GHGE balances, and ecological and environmental impacts can be analyzed by using LCA and SIMAPRO. Internationally certified and reliable data for calculating energy and impacts are available in Agrifootprint, GHG protocol, Ecoinvent, etc., all incorporated in SIMAPRO.

\section{References}

Agri-footprint (2015) Agri-footprint 2.0 Part 1: Methodology and basic principles. Manual. Retrieved September 17, 2018 from www.agri-footprint.com

Bowers W (1992) Agricultural field equipment. In: Fluck RC (ed) Energy in farm production, vol 6. Energ World Agric, New York, pp 117-129

Brodt S, Kendall A, Mohammadi Y, Arslan A, Yuan J, Lee IS, Linquist B (2014) Life cycle greenhouse gas emissions in California rice production. Field Crops Res 169:89-98

Budavari Z, Szalay Z, Emi NB, Malmqvist T, Kth BP, Armines IZ, Circe GK, Sintef CW, Cai X, Calcon HS, Tritthart W (2011) Indicators and weighting systems, including normalisation of environmental profiles. Retrieved January 25, 2019 from https://www.sintef.no/globalassets/ project/lore-lca/deliverables/lore-lca-wp5-d5.1-emi_final.pdf

Carrijo DR, Lundy ME, Linquist BA (2017) Rice yields and water use under alternate wetting and drying irrigation: a meta-analysis. Field Crops Res 203:173-180

Consultants Pr (2013) SimaPro LCA Software pre product ecology consultants. Amersfoot, Netherlands

Dalgaard T, Halberg N, Porter JR (2001) A model for fossil energy use in Danish agriculture used to compare organic and conventional farming. Agric Ecosyst Environ 87:51-65

De-Schryver AM, Brakkee KW, Goedkoop MJ, Huijbregts MAJ (2009) Characterization factors for global warming in life cycle assessment based on damages to humans and ecosystems. Environ Sci Technol 43(6):1689-1695

Ecoinvent (2017) Implementation of Ecoinvent 3. Retrieved January 25, 2019 from: http://www. ecoinvent.org/partners/resellers/implementation-of-ecoinvent-3/implementation-of-ecoinvent-3.html

European Commission Joint Research Centre (2009) International Reference Life Cycle Data System (ILCD) Handbook: specific guidance document for gener-ic or average Life Cycle Inventory (LCI) data sets. Draft for public consultation 01 June 2009. jrc.ec.europa.eu

Fusi A, Bacenetti J, González GS, Vercesi A, Bocchi S, Fiala M (2014) Environmental profile of paddy rice cultivation with different straw management. Sci Total Environ 494-495:119-128 
Goedkoop M, Spriensma R (2001) The eco-indicator 99, a damage oriented method for life cycle impact assessment. Pre-Consultant. https://www.pre-sustainability.com/download/ EI99_annexe_v3.pdf

Grassini P, Cassman KG (2011) High-yield maize with large net energy yield and small global warming intensity. Proc Natl Acad Sci U S A 109(4):1074-1079

Guinée JB (ed) (2004) Handbook on life cycle assessment operational guide to the ISO standards. Kluwer Academic Publishers, New York

Guinée JB, Gorrée M, Heijungs R, Huppes G, Kleijn R, Koning A, Oers, L, Sleeswijk AW, Suh S, Udo de Haes HA, Bruijn H, Duin R, Huijbregts MAJ (2001) LCA - An operational guide to the ISO standards, Final report

IPCC (2006) IPCC Guidelines for national greenhouse gas emission inventory,. Retrieved April 9, 2019 from: https://www.ipcc-nggip.iges.or.jp/support/Primer_2006GLs.pdf

IPCC (2013) Emissions Factor Database. Retrieved January 25, 2019 from: http://www.ghgprotocol.org/Third-Party-Databases/IPCC-Emissions-Factor-Database

Jeroen BG, Gjalt H, Reinout H (2001) Developing an LCA guide for decision support. Retrieved April 9, 2019 from: https://www.emeraldinsight.com/doi/abs/10.1108/09566160110392416

Kami DM, Barz M, Gheewala SH, Sajjakulnukit B (2012) Environmental and socioeconomic feasibility assessment of rice straw conversion to power and ethanol in Thailand. J Clean Prod 37:29-41

Kool A, Marinussen M, Blonk H (2012) GHG Emissions of N, P, and K fertilizer production, in LCI data for the calculation tool Feedprint for greenhouse gas emissions of feed production and utilization. Retrieved January 25, 2019 from: http://www.blonkconsultants.nl/wp-content/ uploads/2016/06/fertilizer_production-D03.pdf

Linquist BA, Anders MM, Adviento-Borbe MA, Chaney RL, Nalley LL, da Rosa EF, van Kessel C (2015) Reducing greenhouse gas emissions, water use, and grain arsenic levels in rice systems. Glob Change Biol 21:407-417

Mudahar MS, Hignett TP (1987) Energy requirements, technology, and resources in the fertilizer sector. In: Helsel ZR (ed.), Energy in World Agriculture 2:26-61

Nguyen VH, Topno S, Balingbing C, Nguyen VCN, Roder M, Quilty J, Jamieson C, Thornley P, Gummert M (2016) Generating a positive energy balance from using rice straw for anaerobic digestion. Energy Rep 2016(2):117-122

Nguyen VH, Nguyen DC, Tran VT, Hau DH, Gummert M (2017) Energy efficiency, greenhouse gas emissions, and cost of rice straw collection in the Mekong River Delta of Vietnam. Field Crops Res 198:16-22

Nguyen VH, Sander BO, Quilty J, Balingbing C, Castalone AG, Romasanta R, Alberto MCR, Sandro J, Jamieson C, Gummert M (2019) An assessment of irrigated rice production energy efficiency and environmental footprint with in-field and off-field rice straw management practices. Energy Efficiency Journal, Springer (under review)

Pimentel D, Pimentel M (2008) Food, energy and society, 3rd edn. CRC Press, Boca Raton, FL

Quilty RJ, McKinley J, Pede VO, Buresh RJ, Correa JTQ, Sandro J (2014) Energy efficiency of rice production in farmers' fields and intensively cropped research fields in the Philippines. Field Crops Res. 168:8-18

Richard CF (1992) Chapter 5, energy analysis for agricultural systems. Energ World Agric 6:45-52

Shafie SM, Masjuki HH, Mahlia TMI (2014) Life cycle assessment of rice straw-based power generation in Malaysia. Energy 70:401-410

Shie JL, Chang CY, Chen CS, Shaw DG, Chen YH, Kuan WH, Ma HK (2011) Energy life cycle assessment of rice straw bio-energy derived from potential gasification technologies. Bioresour Technol 102:6735-6741

Silalertruksa T, Gheewala SH (2013) A comparative LCA of rice straw utilization for fuels and fertilizer in Thailand. Bioresour Technol 150:412-419

SIMAPRO (2017) SIMAPRO - LCA software. https://www.pre-sustainability.com/ sustainability-consulting/sustainable-practices/custom-sustainability-software 
Singh A, Pant D, Olsen SI (eds) (2013) Life cycle assessment of renewable energy sources. Green energy and technology. Springer, London. https://doi.org/10.1007/978-1-4471-5364-1_6. https://www.springer.com/gp/book/9781447153634

Suramaythangkoor T, Gheewala SH (2011) Implementability of rice straw utilization and greenhouse gas emission reductions for heat and power in Thailand. Waste Biomass Valor 2:133-147

US EPA (United States Environmental Protection Agency) (2006) Life cycle assessment: principles and practice. Retrieved January 20, 2019 from https://nepis.epa.gov/Exe/ZyPDF.cgi/ P1000L86.PDF?Dockey=P1000L86.PDF

Open Access This chapter is licensed under the terms of the Creative Commons Attribution 4.0 International License (http://creativecommons.org/licenses/by/4.0/), which permits use, sharing, adaptation, distribution and reproduction in any medium or format, as long as you give appropriate credit to the original author(s) and the source, provide a link to the Creative Commons licence and indicate if changes were made.

The images or other third party material in this chapter are included in the chapter's Creative Commons licence, unless indicated otherwise in a credit line to the material. If material is not included in the chapter's Creative Commons licence and your intended use is not permitted by statutory regulation or exceeds the permitted use, you will need to obtain permission directly from the copyright holder.

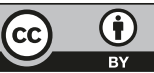

